\title{
Biblical Milk Taboos and Scientific Methodology with Ancient Nomenclature
}

\author{
David Iluz ${ }^{1,2,3}$, Zohar Amar ${ }^{4}$, Michael Goldberg ${ }^{5,6}$, Uzi Merin ${ }^{7}$, Yitzhak Katz ${ }^{5,6}$ \\ ${ }^{1}$ The Mina \& Everard Goodman Faculty of Life Sciences, Bar-Ilan University, Ramat-Gan, Israel; ${ }^{2}$ Talpiot College, Holon, Israel; \\ ${ }^{3}$ Beit Berl College, Kfar Saba, Israel; ${ }^{4}$ Department of Land of Israel Studies and Archaeology, Bar-Ilan University, Ramat-Gan, Israel; \\ ${ }^{5}$ The Allergy and Immunology Institute, Assaf-Harofeh Medical Center, Zrifin, Israel; ${ }^{6}$ Department of Pediatrics, Sackler Faculty of \\ Medicine, Tel Aviv University, Israel; ${ }^{7}$ Department of Food Science, Agricultural Research Organization, Volcani Center, Bet Dagan, \\ Israel. \\ Email:iluzda@gmail.com,iluzda@mail.biu.ac.il
}

Received August 23 ${ }^{\text {rd }}, 2011$; revised October $3^{\text {rd }}, 2011$; accepted October $10^{\text {th }}, 2011$.

\begin{abstract}
Human society and its religions and cultures have laid out numerous guidelines, often involving dietary restrictions (Deut. 14:4-5; Lev. 11:2-7). One such set of restrictions still observed by many Jews today relates to the distinction between pure and impure, edible and forbidden mammals (Talmud Bavli, Avoda Zara 35b). The ancient Jewish dietary laws (kashrut) have often perplexed both gentiles and Jews, since they appear to be arbitrary. Here we demonstrate that the separation of pure and impure animals coincides with taxonomic, biochemical, allergenic, and common nutritional properties.
\end{abstract}

Keywords: Milk, Allergy, Mammals, Kosher

\section{Introduction}

The Biblical passages addressing mammalian kashrut appear in the book of Deut.: "These are the beasts which we may eat: the ox, the sheep, and the goat, the Ayyãl, and the Zěbi and the Yahmữr, and the Aqqổ, and the Dišổn, and the Těổ, and the zemer" (Deut 14:4 - 5). See also (Lev. 11:2 - 7). There are disagreements on some animal's names (see Amar et al. [1]). As one notes from reading the above, the passages listing the rules provide examples of animals to illustrate their application, but does not give any justification.

An additional characteristic distinction between kosher and nonkosher animals was provided by the Talmud ( $\mathrm{T}$. Bavli, Avoda Zara 35b), a collection of Rabbinic notes about the Jewish oral tradition thought completed around the $5^{\text {th }}$ Century AD, as well as the treatise "The Medicine Book of Asaph Harofe" ( $8^{\text {th }}-9^{\text {th }}$ Century AD). Both cite the ability to curdle milk as an additional sign distinguishing between these two groups [2]. According to this criterion, it is only the milk of pure animals that curdles while the milk of impure animals does not. The curdling test was accepted by the medieval philosopher, physician, and theologist, Moses Maimonides (referred to by others as the Rambam) (1138-1204) in his treatise "Mishneh Torah" (The Law in Review) (Maimonides Laws of For- bidden Foods, 3, 12) and in subsequent religious texts.

\section{Methods}

To examine the validity and generality of this criterion, the milk of various mammals was tested by two techniques. The first test was carried out immediately after milking using the enzyme rennin, which is the standard method. The second technique utilized an Optigraph (Ysebaert, Frepillon, France), which is an instrument that measures the clotting time of milk and the degree of firmness of the curd (Figure 1).

Speed tests were carried out on making the coagulation using the Optigraph. $10 \mathrm{ml}$ of sample of milk entered to well on the device, temperature of 30 degree determind. as soon as it reached a temperature set, have been added $0.5 \mathrm{ml}$ of coagulation enzyme solution-Fromase 15 TL (Gist-Brocades nv, Delft, The Netherlands) for coagulation speed of 600 seconds. the degree of firmness of the curd is determined by the intensity of transmission intensity light (in volts).

\section{Description of the Optigraph Device Operations}

The optigraph measures the intensity of the Near Infra Red light beam in through one centimeter of the milk sample, located in quartz glass. Reading in volts, treated 


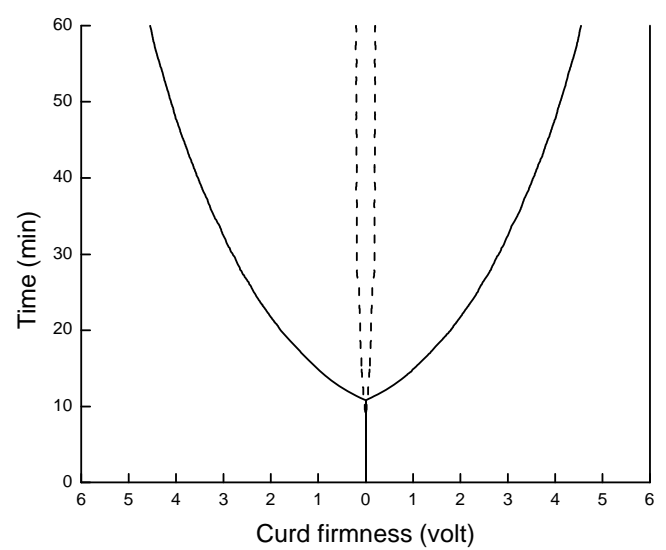

Figure 1. Example of results of curdling dairy cow (continuous line) as opposed to horse (dashed line) as speed tests, coagulation and strength are obtained using the optigraph device.

as mathematical power for drawing a shape like champagne glass. A straight line from the bottom of the curve to the start of opening walls of the Cup is the time that passes through the point of clotting (beginning of cheese making) as soon as milk start making a cheese, the curves are opened due to strongest of cheese. The walls of the Cup describes the strength of cheese and Creates a drawing of a typical champagne Cup, with arbitrary values of volts, called every few seconds and a continuous curve.

Patients with a clinical history consistent with IgEmediated CMP allergy and a positive skin-prick test (SPT) were evaluated for cross-sensitization to milk-derived proteins from both kosher and non-kosher species. On the other hand, in experimentation, milks were tested for their ability to curdle after the addition of rennin, and clotting time and degree of firmness were quantitated by the Optigraph method.

\section{Results}

The results of the analyses showed the formation of curdling in the milk of the cow (Bos taurus), sheep (Ovis aries), goat (Capra aegagrus hircus), buffalo (Bubalus bubalis), fallow deer (Dama d. dama), red deer (Cervus elaphus), ibex (Capra ibex), and the reticulated giraffe (Giraffa camelopardalis reticulate) —all defined as ritually pure animals. In contrast, no curdling was observed in the milk of the mammals which the Torah defines as ritually impure: the horse (Equus caballus), donkey (Equus asinus), camel (Camelus dromedaries), alpaca (Lama pacos), pig (Sus scrofa domestica), rabbit (Oryctolagus cuniculus), monkey (Macaca fascicularis), and dog (Canis familiaris). Human milk was also included in this category (Figure 2).

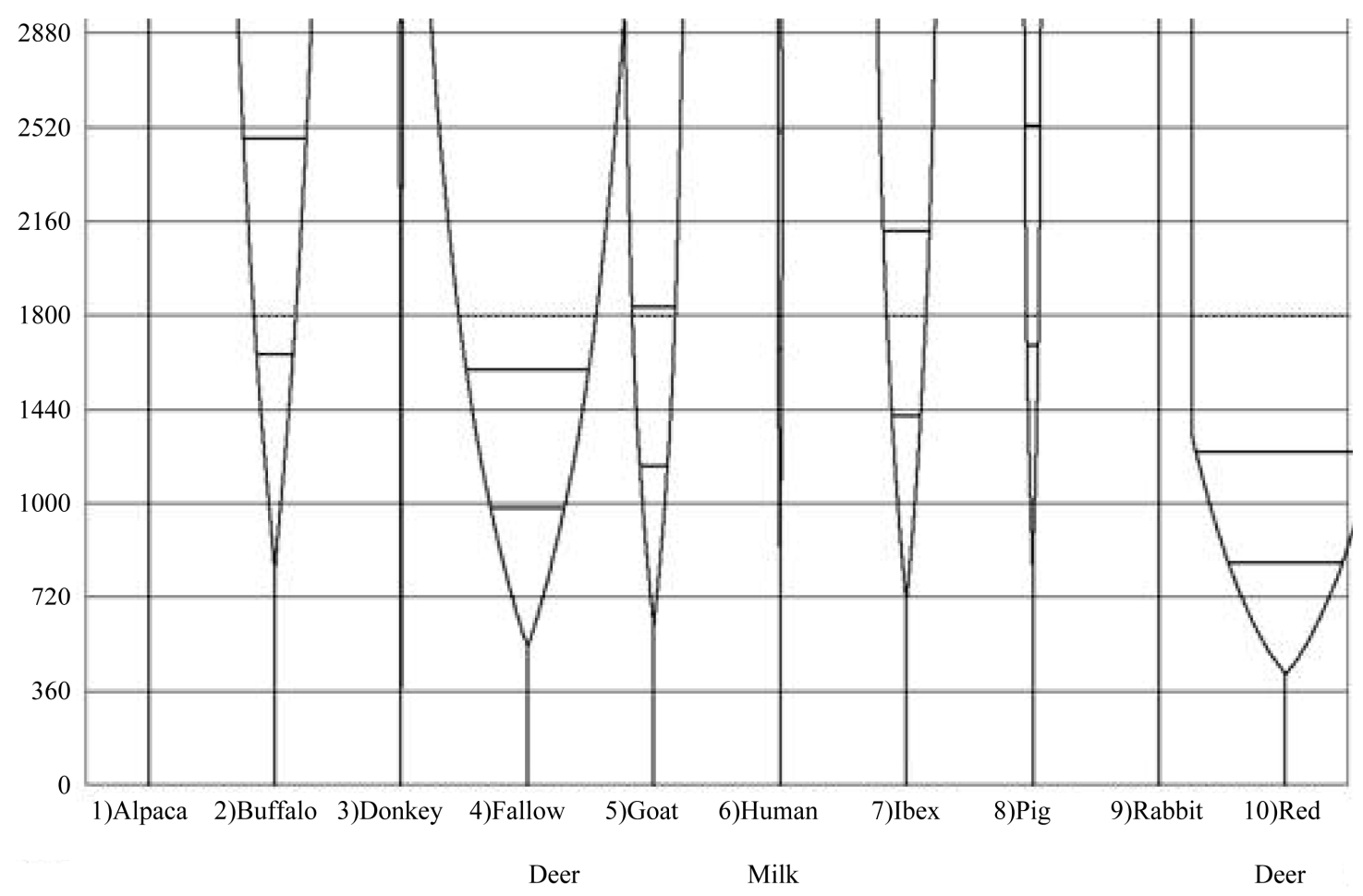

Figure 2. Results of testing clotting of different dairy mammals as they are graphically; shows two arms that create a kind of anti-shaped cup, those are pure animals while a straight line or narrow shows impure animals. The values on the vertical axis shows the time in seconds until the beginning of clotting. 
Another common denominator shared by the milks of the various kosher-animal species is their allergenic potential. The impetus to study the allergenic potential of kosher-versus nonkosher-derived milk was based on an intriguing article demonstrating that the evolutionary relationships of kosher-animal milk casein genes were more closely related to each other than to nonkosher species (Figure 3) [3] (casein is one of the more highly allergenic proteins in milk).

This was followed by a study aimed at determining whether a patient allergic to the IgE in cow's milk showed differences in cross reactivity to kosher versus non-kosher animals [4]. All the patients who were allergic to cow's milk protein (CMP) tested positive by the skin-prick test (SPT) for cross-reactivity to goat, ibex, and giraffe $(\mathrm{n}=$ $27, \mathrm{p}=0$ ). In contrast, reactivity to milk from the nonkosher animal species was significantly lower: only one out of 22 patients $(4.5 \%)$ cross-reacted to milk of horse, 6/27 (20.83\%) to pig, $7 / 27$ (25.9\%) to dog, $5 / 27$ to alpaca (18.5\%), $5 / 27$ to camel (18.5\%), and $3 / 27(11.1 \%)$ to rabbit. Eight controls did not react to any of the milk species tested (Figure 4). Indeed, camel milk has been suggested as a protein source for nutrition for children allergic to cow milk [5].

We, thus, began to try to find out whether there were any unique sequences that would explain why milkprotein allergy could be divided into responses to kosher and nonkosher. We noted that a unique stretch of eight amino acids is common to the $\kappa$-casein of the milk from all kosher (pure) animals [6]. This sequence is not present in the $\kappa$-casein of any of the non-pure animals. It is noteworthy that while no detailed mechanism has been published for the curdling of milk in general [7], it is generally accepted that the firmness of the curd requires the

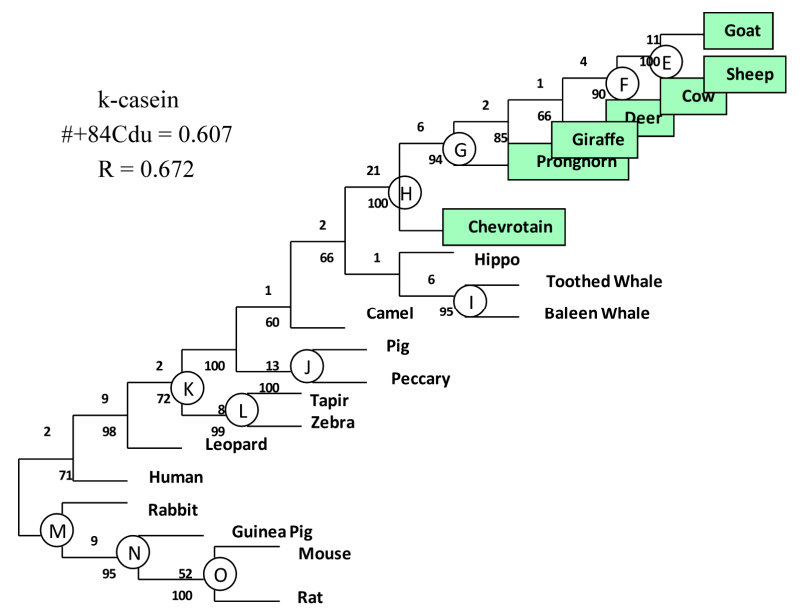

Figure 3. Taxonomic relationships of pure versus impure mammals (after Gatesy et al. 1996 [3]). The pure mammals are marked.

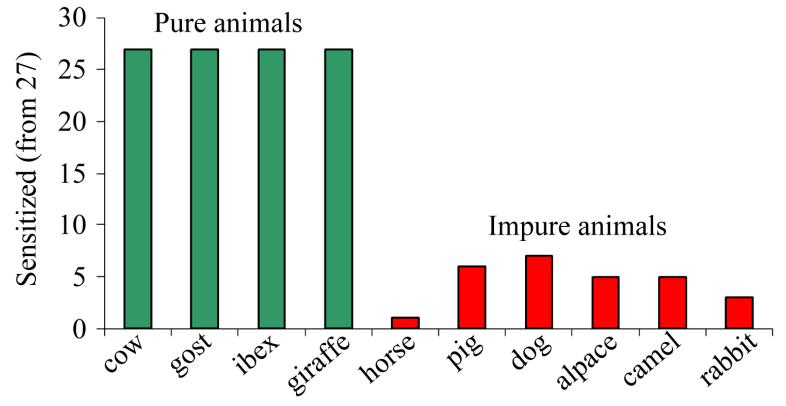

Figure 4. Allergenic responses of patients sensitized to cow's milk to milk of pure and impure mammals.

formation of casein multimers, which would be facilitated by the cysteine present in this eight-amino-acid stretch.

One has to marvel at the fact that the Biblical distinction between kosher and nonkosher can be re-established based on modern methods and parameters totally unknown in antiquity.

\section{Acknowledgements}

The authors thank Prof. Zvy Dubinsky of Bar-Ilan University, Israel, for advice and comments. We thank Sharon Victor for the English editing

\section{REFERENCES}

[1] Z. Amar, R. Bouchnick and G. Bar-Oz, "The Contribution of Archaeozoology to the Identification of the Ritually Clean Ungulates Mentioned in the Hebrew Bible," Journal of Hebrew Scriptures, Vol. 10, 2009, pp. 2-24.

[2] Z. Montener, "Introduction to Asaph Harofe Book," Korot, Jerusalem, 1958.

[3] J. Gatesy, C. Hayashi, M. A. Cronin and P. Arctander, "Evidence from Milk Casein Genes that Cetaceans are Close Relatives of Hippopotamid Artiodactyls," Molecular Biology and Evolution, Vol. 13, No. 7, 1996, pp. 954-963.

[4] Y. Katz, M. R. Goldberg, G. Zadik-Mnuhin, M. Leshno and E. Heyman, "Cross-Sensitization between Milk Proteins: Reactivity to a "Kosher" Epitope?" Israel Medical Association Journal, Vol. 10, No. 1, 2008, pp. 85-88.

[5] E. I. El-Agamy, M. Nawar, S. M. Shamsi, S. Awad and F. W. Haenlein, "Are Camel Milk Proteins Convenient to the Nutrition of Cow Milk Allergic Children?" Small Ruminant Research, Vol. 82, 2009, pp. 1-6. doi:10.1016/j.smallrumres.2008.12.016

[6] M. Goldberg, R. Friedman and Y. Katz, "A Unique 8Amino Acid Stretch Defines the Kappa-casein Sequence of Kosher Animal Species: Responsible for cross Sensitization between Milk Proteins?," Journal of Allergy and Clinical Immunology, Vol. 123, No. 2, 2009, p. S183. doi:10.1016/j.jaci.2008.12.694

[7] T. Ikonen, S. Morri, A. M. Tyrisevä, O. Ruottinen and M. 
Ojala, "Genetic and Phenotypic Correlations between Milk Coagulation Properties, Milk Production Traits, Somatic Cell Count, Casein Content, and pH of Milk,"
Journal of Dairy Science, Vol. 87, No. 2, 2004, pp. 458467. doi:10.3168/jds.S0022-0302(04)73185-9 